\title{
Effects of short-term storage of gametes on fertilization of Pacific herring eggs"
}

\author{
D. F. Alderdice \& F. P. J. Velsen \\ Department of Fisheries and the Environment, Fisheries and Marine Service, \\ Pacific Biological Station; Nanaimo, B.C. V9R 5K6, Canada
}

\begin{abstract}
A method is described whereby arrays of samples of Clupea pallasi eggs may be stored during their preparation. The high fertilization potential retained by the eggs during short-term storage allows them to be fertilized synchronously when sample preparation is complete. A variation of the " $\mathrm{dry}$ " method of storage retained maximum fertilization potential (80-85\%) of the eggs for about $1 \mathrm{hr}$, and of milt dilution $(1: 8$ with $17 \% \mathrm{~S}$ sea water), about $7 \mathrm{hr}$. Following dry storage, eggs fertilized in salinities of $0-45 \%$ showed maximum rates of fertilization in salinities of 10-20\%, and fertilization rates $>50 \%$ in salinities of $4.5-42 \%$. Salinities of fertilization influenced egg diameter, median hatching time, and larval length at hatching in egg samples transferred $2^{1 / 2} \mathrm{hr}$ after fertilization to an incubation salinity of $17 \%$ at $7{ }^{\circ} \mathrm{C}$. Fertilization rates were higher (90-95\%) for eggs stored in $17 \% \mathrm{~S}$ at $7{ }^{\circ} \mathrm{C}$ prior to fertilization. Under such "wet" storage conditions, maximum fertilization potential was retained for about $2 \mathrm{hr}$. Highest fertilization rates (95-96\%) were obtained for eggs stored and fertilized in salinities of 12-15\%. For the species and the area of origin considered (British Columbia), wet storage of eggs should result in maximum fertilization when the eggs are stored at $4{ }^{\circ} \mathrm{C}$ for a period not greater than $2 \mathrm{hr}$ prior to fertilization in the $12-15 \% \mathrm{~S}$ storage medium.
\end{abstract}

\section{INTRODUCTION}

Investigation of the influence of environmental factors on development of Pacific herring (Clupea pallasi) eggs often has required our preparation of large arrays of individual egg samples (e.g. 400 eggs $\times 4$ replicates $\times 15$ trials). It is convenient if such samples can be prepared for simultaneous fertilization to facilitate rapid identification of deviations from expected states or rates of development. However, preparation of these sample arrays may require several hours, leading to variations in age of individual samples prior to fertilization. If variations in short-term storage time of egg samples prior to fertilization lead to differences in fertilization potential of the eggs, then bias could be introduced into the sample array. Obviously, an examination of the effects of sample storage would be useful.

* Prepared under the auspices of the Canadian-German Scientific and Technical Cooperation Agreement. 
The length of time stored teleost eggs will retain their fertilization potential varies between species from less than 1 min to many hours (Ginzburg, 1972). Conditions of storage also have a marked influence on fertilization potential. In general, eggs stored in ovarian or body cavity fluid retain their fertilization potential longest. Those stored in physiological saline retain their potential for a shorter period, and those stored in water have the shortest period. Also, lower temperatures lengthen the storage period in which fertilization potential is retained.

The fertilization potential of stored sperm also varies between species (Ginsburg, 1972). Sperm of fishes that spawn in marine or brackish waters retains its motility longer than that of fishes spawning in fresh water. In many species, sperm motility is highest in salinities of 1-2 to $10 \%$, including both marine and freshwater fishes. In general, fertilization potential is retained longest in sperm stored at low temperatures. The very low temperatures provided by cryogenic techniques will not be considered here.

Blaxter (1955) found that eggs and sperm of the Atlantic herring (Clupea barengus) would retain near-maximum fertilization potential $(\sim 90 \%)$ when stored dry at low temperatures $\left(4^{\circ} \mathrm{C}\right)$, the period of near-maximum potential being somewhat greater than $48 \mathrm{hr}$. Yanagimachi (1953) stored eggs and sperm of Clupea pallasi in different media. He found that eggs retained highest fertilization potential in $M / 8$ and $M / 16$ Ringers solution; a lower potential was obtained in one-quarter sea water. The fertilization potential of sperm was retained longest in $M / 2$ to $M / 8$ Ringers solution.

This paper examines the question of gamete storage primarily by comparing rates of fertilization achieved for (a) eggs and milt stored for various periods prior to fertilization, and (b) eggs stored "dry" in a cold humidity chamber, or in waters of various salinities, prior to fertilization. Physiological saline was not used, it being assumed that dilutions of sea water would provide more direct opportunities for ecological interpretation of the results.

\section{MATERIALS AND METHODS}

Gametes were obtained from ripe herring caught in Georgia Strait, British Columbia, and transported live to the Pacific Biological Station, Nanaimo, on February 25, 1972. The fish were held in large circular seawater tanks at ambient conditions $\left(28-29 \% \mathrm{~S}, 8{ }^{\circ} \mathrm{C}\right)$. About $24 \mathrm{hr}$ prior to use, a portion of the stock was segregated by sex, moved to two 780-1 tanks in the laboratory, held under the same ambient conditions.

Four experiments were conducted (Table 1). In each experiment, egg samples were prepared by depositing them in rows onto $4 \times 8-\mathrm{cm}$ strips of monofilament nylon mesh. Milt samples were prepared as a dilution $(1: 8)$ with $17 \% 0 \mathrm{~S}$ sea water. Both were stored (Table 1) until fertilization. A contact time of $10 \mathrm{~min}$ was provided during fertilization. Thereafter the eggs were rinsed in and moved to water generally of the same salinity as that used during fertilization. Success of fertilization was noted 21-24 hr later. 
Table 1

Conditions of storage and fertilization in the four experiments. In Experiments 1 and 2 the eggs were stored "dry" in the humidity chamber; in Experiments 3 and 4 the eggs were stored in salt water. In all instances, milt samples were stored in the humidity chamber at $4^{\circ} \mathrm{C}$ prior to final dilution at fertilization. Final milt dilutions $(\mathrm{ml} / 100 \mathrm{ml}$ ) represent millilitres of original milt per $100 \mathrm{ml}$ of fertilization medium

\begin{tabular}{|c|c|c|c|c|c|c|c|}
\hline \multirow[b]{3}{*}{$\begin{array}{c}\text { Experi- } \\
\text { ment }\end{array}$} & \multicolumn{4}{|c|}{ Storage } & \multicolumn{3}{|c|}{ Fertilization } \\
\hline & & Eggs & & Milt & & & Milt \\
\hline & $\begin{array}{c}\text { Tem- } \\
\text { perature } \\
\left({ }^{\circ} \mathrm{C}\right)\end{array}$ & $\begin{array}{c}\text { Salinity } \\
\left.(\%)_{0}\right)\end{array}$ & $\begin{array}{l}\text { Time } \\
\text { (min) }\end{array}$ & $\begin{array}{l}\text { Time } \\
(\min )\end{array}$ & $\begin{array}{c}\text { Tem- } \\
\text { perature } \\
\left({ }^{\circ} \mathrm{C}\right)\end{array}$ & $\begin{array}{c}\text { Salinity } \\
(\% \% 0)\end{array}$ & $\begin{array}{c}\text { Final } \\
\text { dilution } \\
(\mathrm{ml} / 100 \mathrm{ml})\end{array}$ \\
\hline 1 & 4 & - & $0-267$ & $0-229$ & 6.5 & 17 & 0.019 \\
\hline 2 & 4 & - & $18-36$ & $36-49$ & 6.5 & $0-45$ & 0.031 \\
\hline 3 & 7 & 17 & $0-246$ & $26-267$ & 7 & 17 & 0.025 \\
\hline 4 & 7 & $10-30$ & $61-64$ & $49-54$ & 7 & $10-30$ & 0.025 \\
\hline
\end{tabular}

In Expts 1 and 2 (Table 1), the eggs were stored "dry" in a cold humidity chamber. The chamber consisted of a stainless steel tray, a floor of absorbent paper saturated with $17 \%$ S sea water and covered by a neoprene mat upon which the egg samples were laid, and a Plexiglas cover. Milt samples were held separately in a beaker in the chamber. In Expt. 1, the eggs were fertilized in $17 \%$ S sea water. In Expt. 2, the eggs were fertilized in 12 salinities ranging from 0 to $45 \%$; in addition, $21 / 2$ hr after fertilization $\left(17 \% 0 \mathrm{~S}, 6.5^{\circ} \mathrm{C}\right)$ the eggs were moved to incubation $\left(17 \% \mathrm{~S}, 7^{\circ} \mathrm{C}\right)$ and held for further observation. In Expts 3 and 4 the eggs were stored "wet" prior to fertilization - in $17 \% 0 \mathrm{~S}$ sea water in Expt. 3 and in nine salinities ranging from 10 to $30 \%$ in Expt. 4.

\section{RESULTS}

In the first experiment (Table 2, Fig. 1) storage of eggs (34-267 min) and milt (22-229 $\mathrm{min})$ in the humidity chamber resulted in control levels of fertilization $(80-85 \%)$ or better for approximately $60 \mathrm{~min}$ of storage. Fertilization rates then declined to $60-65 \%$ between 2 and $3^{1 / 2} \mathrm{hr}$ after fertilization. Thereafter fertilization success declined more rapidly. Freshly spawned eggs, fertilized with stored milt (0-2906 $\mathrm{min}$ ), yielded control fertilization rates (80-85\%) for about $120 \mathrm{~min}$ of sperm storage; there followed a variable but suggested increase in fertilization rates that lasted at least until $7 \mathrm{hr}$ after preparation of the milt sample. Thereafter fertilization rates declined to $35.3 \%$ at the end of the second day of milt storage. Stored eggs (28-257 min) fertilized with fresh milt samples showed a continuous decline in fertilization rates from the control level attained in the first egg samples stored for $28 \mathrm{~min}$. Comparison of the latter results with those in the first series, where both eggs and milt were stored, indicates that loss of fertilization potential in the first series would be attributed the storage of the eggs. 
Table 2

Effect of storage of Pacific herring eggs and milt on fertilization success. Storage conditions: humidity chamber at $4{ }^{\circ} \mathrm{C}$. Fertilization: in $17 \%$ S sea water at $6.5^{\circ} \mathrm{C}$

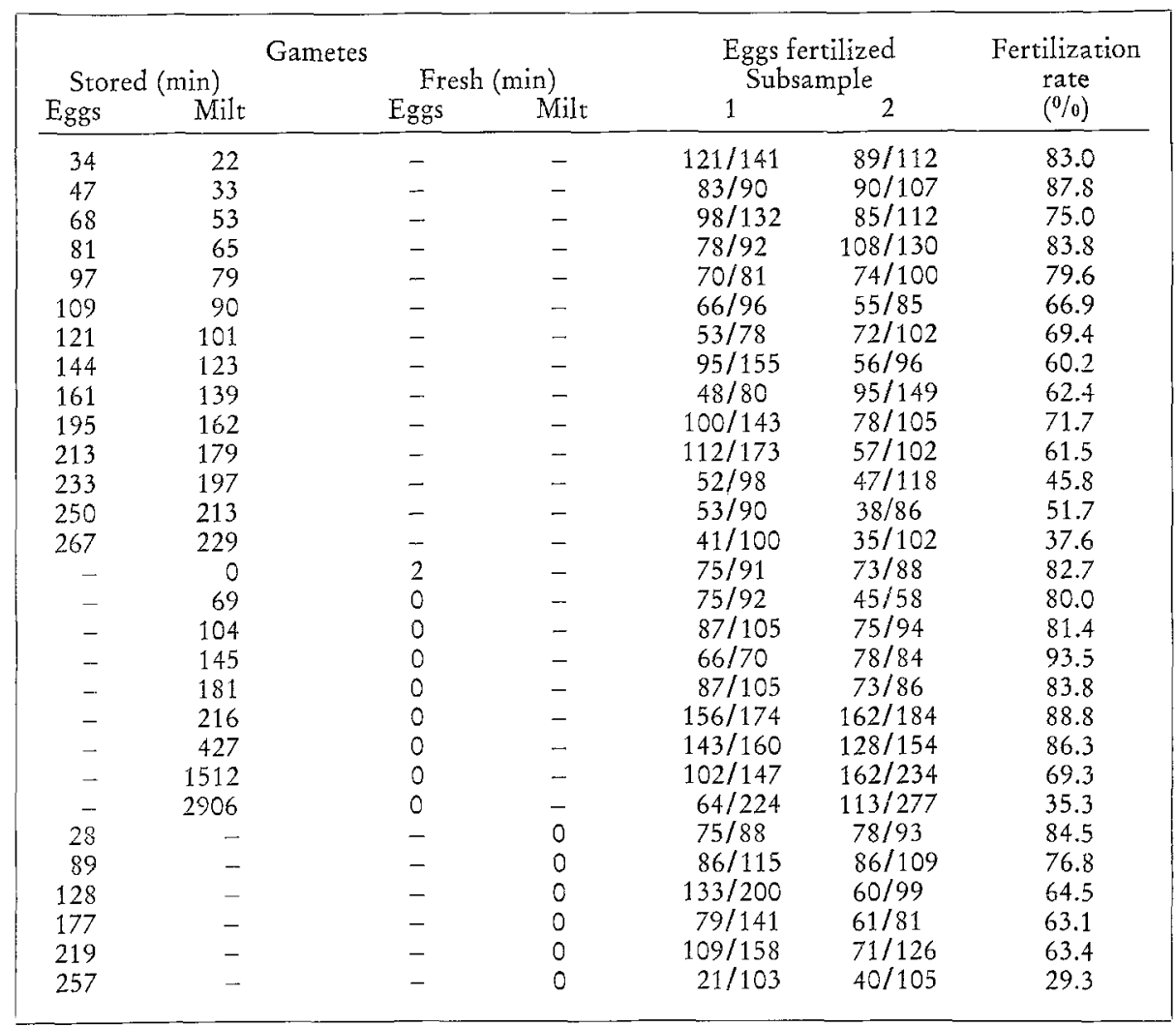

In the three series of trials in Expt. 1, storage of eggs in the humidity chamber appeared to affect the "jelly coat" surrounding the egg capsule. Patches of brownish discoloration were evident in many of these eggs, although discoloration was not correlated with reduction in fertilization potential.

In summary, Pacific herring eggs stored in a humidity chamber at $4{ }^{\circ} \mathrm{C}$ maintained control levels of fertilization potential for about $1 \mathrm{hr}$. Samples of milt stored at $4{ }^{\circ} \mathrm{C}$ maintained their initial fertilization potential for a least $7 \mathrm{hr}$. Loss of fertilization potential occurred primarily as a result of storage of the eggs.

In the second experiment eggs were stored in the humidity chamber for a period $(18-36 \mathrm{~min})$ within that providing maximum fertilization potential $(1 \mathrm{hr})$ indicated in the first experiment. Following egg storage, fertilization rates in the 12 fertilization salinities employed (0-45\%) were similar $(85-88 \%)$ for salinities ranging from 10 to $30 \%$ (Table 3 ). Fertilization rates declined sharply at salinities below $10 \%$ and above approximately $35 \%$. Graphic analysis suggests that a fertilization potential of $50 \%$ or more would be expected within a salinity range of 4.5 to $42 \%$ at $6.5^{\circ} \mathrm{C}$. 


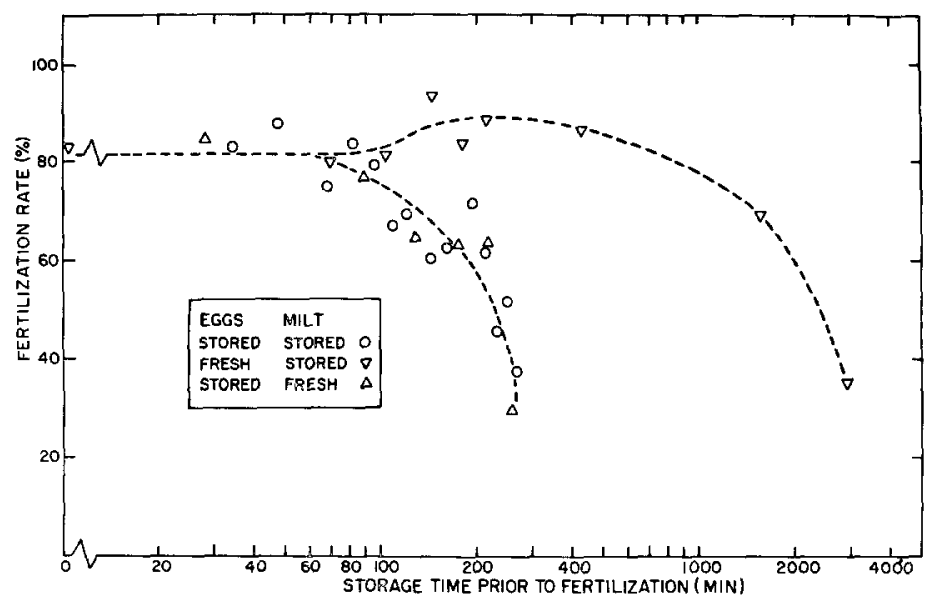

Fig. 1: Fertilization rates for Pacific herring eggs following storage of the male and female gametes. Eggs: "dry" storage of prepared samples in a humidity chamber; milt: stored as a dilution, $1: 8$ with $17 \% \mathrm{~S}$ sea water. Storage temperature, $4{ }^{\circ} \mathrm{C}$. "Fresh" eggs and milt: prepared from the live adult in the same manner, without storage

The eggs fertilized in the 12 salinities were transferred to $17 \% \mathrm{~S}$ sea water, $2^{1 / 2}$ hr after fertilization. Samples of egg measured $45^{1 / 2}$ hr following transfer (Table 4) show that those fertilized in the lower salinities $(2.5-17 \%$ ) were somewhat larger in diameter. Apparently, exposure of the eggs to a given salinity during fertilization, and for $2^{1 / 2} \mathrm{hr}$ thereafter, is sufficient to influence pressure-volume relations during imbibition so that the effects are retained even after transfer of the eggs to another salinity $(17 \%$ ).

\section{Table 3}

Fertilization rates of Pacific herring eggs after short-term storage (18-36 $\mathrm{min}$ ) of gametes in the humidity chamber at $4{ }^{\circ} \mathrm{C}$, when fertilized thereafter in salinities ranging from 0 to $45 \%$ $\left(6.5^{\circ} \mathrm{C}\right)$. Two and one-half hours after fertilization the eggs were transferred to $17 \% 0 \mathrm{~S}$ sea water at $7^{\circ} \mathrm{C}$ where incubation continued

\begin{tabular}{|c|c|c|c|c|}
\hline \multicolumn{2}{|c|}{ Fertilization S $(\%)$} & \multicolumn{2}{|c|}{$\begin{array}{l}\text { Eggs fertilized } \\
\text { Subsample }\end{array}$} & \multirow{2}{*}{$\begin{array}{c}\text { Average } \\
(\% / 0)\end{array}$} \\
\hline Nominal & Actual & $1^{32}$ & 2 & \\
\hline 0 & 0 & $0 / 100$ & $3 / 165$ & 1.1 \\
\hline 2.5 & 2.45 & $5 / 108$ & $4 / 104$ & 4.3 \\
\hline 5 & 5.07 & $60 / 107$ & $78 / 112$ & 63.0 \\
\hline 10 & 10.04 & $121 / 135$ & $115 / 132$ & 88.4 \\
\hline 15 & 14.94 & $112 / 126$ & $88 / 104$ & 87.0 \\
\hline 17 & 17.00 & $144 / 162$ & $153 / 183$ & 86.1 \\
\hline 20 & 20.00 & $100 / 115$ & $100 / 116$ & 86.6 \\
\hline 25 & 25.07 & $152 / 176$ & $146 / 174$ & 85.1 \\
\hline 30 & 29.98 & $100 / 113$ & $94 / 110$ & 87.0 \\
\hline 35 & 34.94 & $133 / 180$ & $132 / 156$ & 78.9 \\
\hline 40 & 40.02 & $69 / 108$ & $75 / 105$ & 67.6 \\
\hline 45 & 45.02 & $28 / 205$ & $59 / 112$ & 27.4 \\
\hline
\end{tabular}


Table 4

Mean diameters of Pacific herring eggs stored in a humidity chamber, fertilized in salinities of 0 to $45 \% 0$ at $6.5^{\circ} \mathrm{C}$, and transferred $2 \frac{1}{2}$ hr later to $17 \% 0 \mathrm{~S}$ sea water at $7^{\circ} \mathrm{C}$. Egg diameters were measured $45^{1 / 2}$ hr after transfer

\begin{tabular}{|cccc|}
\hline $\begin{array}{c}\text { Salinity of } \\
\text { fertilization } \\
(\% 0)\end{array}$ & $\begin{array}{c}\text { Egg diameter }(\mathrm{mm}) \\
\text { Mean } \pm 1 \mathrm{SE}\end{array}$ & $\begin{array}{c}\text { Salinity of } \\
\text { fertilization } \\
(\% 0)\end{array}$ & $\begin{array}{c}\text { Egg diameter (mm) } \\
\text { Mean } \pm 1 \mathrm{SE}\end{array}$ \\
\hline 0 & $1.71 \pm 0.06$ & 20 & $1.71 \pm 0.04$ \\
2.5 & $1.78 \pm 0.04$ & 25 & $1.68 \pm 0.04$ \\
5 & $1.75 \pm 0.03$ & 30 & $1.66 \pm 0.04$ \\
10 & $1.79 \pm 0.03$ & 35 & $1.68 \pm 0.03$ \\
15 & $1.75 \pm 0.03$ & 40 & $1.65 \pm 0.05$ \\
17 & $1.74 \pm 0.03$ & 45 & $1.67 \pm 0.02$ \\
\hline
\end{tabular}

Median hatching times of larvae from the 12 salinities varied by a maximum of about $26 \mathrm{hr}$. Longest incubation periods to $50 \%$ hatch occurred in fertilization salinities of 15 and $17 \%$, and $35 \%$ (Table 5). Incubation periods for eggs fertilized in 40 and $45 \% \mathrm{~S}$ were significantly shorter $(P<.05)$, and those for eggs fertilized in 2.5 and $5 \% \mathrm{~S}$ were shortest of all. In addition, total hatch and hatch of normal larvae were highest for eggs fertilized in salinities of 15 to $20 \%$ (Table 5). The salinities of fertilization associated with $50 \%$ hatch were not measurably different from those providing $50 \%$ fertilization (about 4.5 and $42 \%$ ) (Fig. 2).

Total length of newly hatched larvae, averaged daily over the hatching period (Fig. 3), followed the same pattern in each fertilization salinity. In almost all

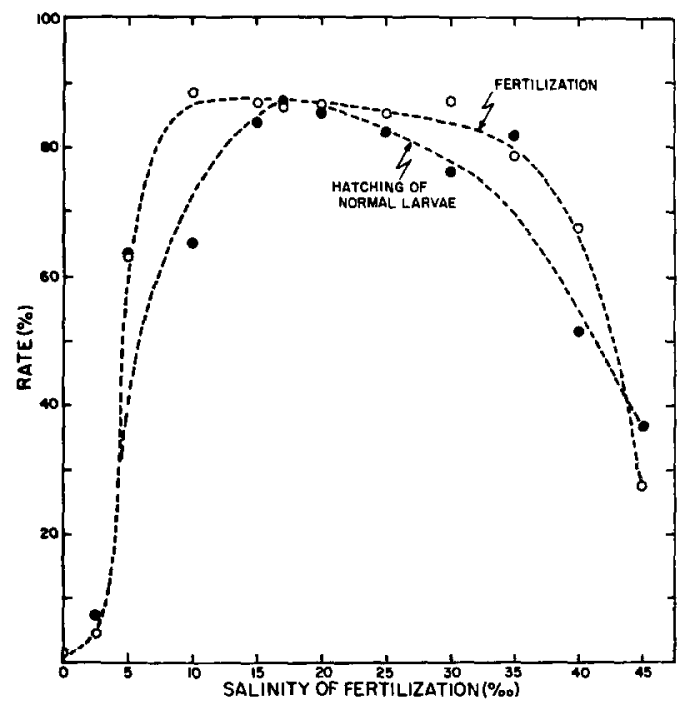

Fig. 2: Ferrilization rates and percentage of the eggs producing normal larvae for Pacific herring egg stored in a humidity chamber $\left({ }^{\circ} \mathrm{C}\right)$ and fertilized in 12 salinities from 0 to $45 \%$. Two and one-half hours after fertilization the eggs were moved to $17 \% \mathrm{~S}$ sea water at $7^{\circ} \mathrm{C}$ for incubation until hatching 
Table 5

Median hatching times, hatching rates for all larvae and for normal larvae, and maximum total length of newly hatched larvae obtained for eggs fertilized in salinities of 0 to $45 \%\left(6.5^{\circ} \mathrm{C}\right)$ and transferred $2 \frac{1}{2} \mathrm{hr}$ after fertilization to $17 \% 0 \mathrm{~S}\left(7^{\circ} \mathrm{C}\right)$ until incubation and hatching were complete. Average number of eggs per trial and range: 871 and 719-1051

\begin{tabular}{|c|c|c|c|c|c|c|}
\hline \multirow{2}{*}{$\begin{array}{l}\text { Fertilization } \\
\text { Salinity } \\
(\% 0)\end{array}$} & \multirow{2}{*}{$\begin{array}{l}\text { Median hatching } \\
\text { time } \\
\text { (hr) }\end{array}$} & \multicolumn{4}{|c|}{ Hatched larvae } & \multirow{2}{*}{$\begin{array}{c}\text { Max. length } \\
\overline{\mathrm{x}} \pm 2 \mathrm{SE} \\
(\mathrm{mm})\end{array}$} \\
\hline & & (N) & $(\%)$ & $(\mathrm{N})$ & 1 & \\
\hline 0 & $454-502$ & 3 & 0.003 & 4 & 0.004 & - \\
\hline 2.5 & 496.3 & 54 & 7.1 & 55 & 7.2 & $10.12 \pm 0.20$ \\
\hline 5 & 496.1 & 459 & 63.8 & 467 & 65.0 & $9.69 \pm 0.22$ \\
\hline 10 & 514.3 & 644 & 65.0 & 659 & 66.5 & $9.98 \pm 0.22$ \\
\hline 15 & 518.9 & 653 & 83.7 & 666 & 85.4 & $9.86 \pm 0.20$ \\
\hline 17 & 521.9 & 829 & 87.2 & 847 & 89.1 & $9.64 \pm 0.16$ \\
\hline 20 & 506.6 & 749 & 85.2 & 764 & 86.9 & $9.47 \pm 0.24$ \\
\hline 25 & 511.1 & 752 & 82.2 & 771 & 84.3 & $9.56 \pm 0.20$ \\
\hline 30 & 514.5 & 688 & 76.2 & 710 & 78.6 & $9.35 \pm 0.14$ \\
\hline 35 & 519.9 & 681 & 81.9 & 688 & 82.8 & $9.52 \pm 0.26$ \\
\hline 40 & 506.9 & 478 & 51.5 & 493 & 53.1 & $9.49 \pm 0.14$ \\
\hline 45 & 509.7 & 275 & 36.8 & 292 & 39.0 & $9.56 \pm 0.25$ \\
\hline
\end{tabular}

instances maximum length of newly hatched larvae (Table 5) was achieved on the fifth hatching day. Maximum total length was approximately $9.4-9.6 \mathrm{~mm}$ in fertilization salinities of $17 \%$ or greater, and tended to increase in the lower salinities $(9.6-10.1 \mathrm{~mm})$.

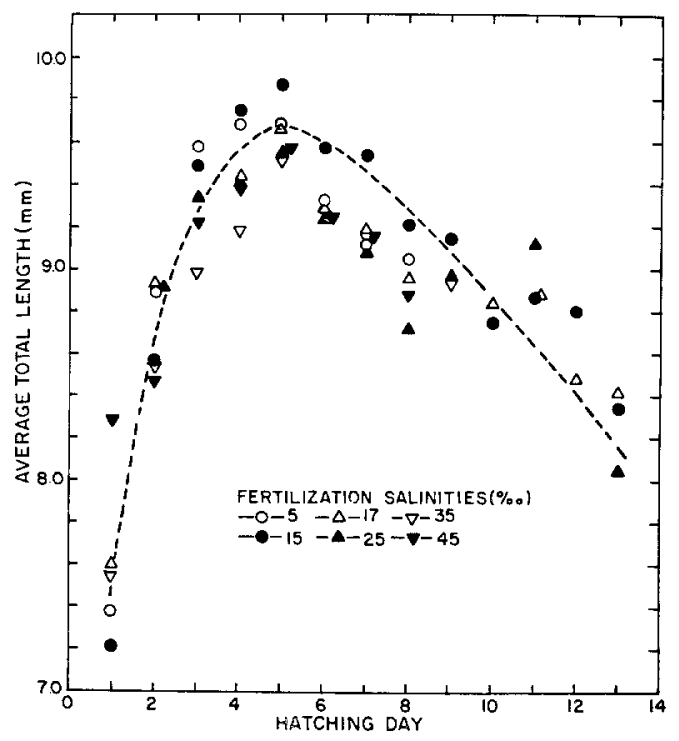

Fig. 3: Mean daily total length of newly hatched larvae for eggs fertilized in salinities of 0-45\% at $4{ }^{\circ} \mathrm{C}$ and moved $21 / 2 \mathrm{hr}$ after fertilization to $17 \% \mathrm{~S}$ at $7{ }^{\circ} \mathrm{C}$ for incubation. Representative distribution are shown for fertilization salinities of $5,15,17,25,35$, and $45 \% 0$ 
Table 6

Percentage fertilization of Pacific herring eggs stored in $17 \%$ S sea water at $7^{\circ} \mathrm{C}$ for various times prior to fertilization. Milt diluted $1: 8$ with $17 \% 0 \mathrm{~S}$ sea water and stored at $4{ }^{\circ} \mathrm{C}$

\begin{tabular}{|ccccc|}
\hline \multicolumn{2}{|c}{$\begin{array}{c}\text { Storage time in } 17 \% \text { S } \\
\text { Eggs } \\
(\mathrm{min})\end{array}$} & $\begin{array}{c}\text { Milt } \\
(\mathrm{min})\end{array}$ & 1 & \multicolumn{2}{c}{ Eggs fertilized } & $\begin{array}{c}\text { Fertilization } \\
\text { Sate } \\
(\%)\end{array}$ \\
\hline 0 & 26 & $137 / 149$ & $135 / 153$ & 90.1 \\
16 & 42 & $141 / 158$ & $123 / 137$ & 89.5 \\
32 & 57 & $157 / 166$ & $130 / 143$ & 92.9 \\
47 & 72 & $152 / 161$ & $131 / 133$ & 96.3 \\
63 & 87 & $131 / 137$ & $153 / 163$ & 94.7 \\
78 & 102 & $147 / 151$ & $269 / 291$ & 94.1 \\
93 & 117 & $160 / 162$ & $145 / 158$ & 95.3 \\
124 & 147 & $137 / 141$ & $236 / 256$ & 94.0 \\
169 & 192 & $93 / 171$ & $84 / 133$ & 58.2 \\
185 & 207 & $125 / 187$ & $118 / 209$ & 61.4 \\
216 & 238 & $65 / 168$ & $69 / 161$ & 41.0 \\
246 & 267 & $41 / 170$ & $31 / 255$ & 16.9 \\
\hline
\end{tabular}

In summary, Pacific herring eggs stored in a humidity chamber, fertilized in various salinities at $6.5^{\circ} \mathrm{C}$, and transferred $2^{1 / 2}$ hr after fertilization to $17 \%$ sea water at $7{ }^{\circ} \mathrm{C}$ showed (a) maximum fertilization rates in salinities of $10-30 \%$ with fertilization rates $>50 \%$ for salinities of $4.5-42 \%$, (b) longest incubation periods after fertilization in $15-17 \%$ and shortest periods in 2.5-5\%, and (c) maximum percentages of hatched larvae from fertilization salinities of 15-20\% with percentages $>50 \%$ for salinities of $4.5-42 \%$. In addition, eggs fertilized in salinities of $2.5-17 \%$ remained somewhat larger in diameter after transfer to $17 \% \mathrm{~S}$ than eggs fertilized in higher salinities, and larvae hatching from those eggs tended to be slightly longer for fertilization salinities of $2.5-15 \%$.

In the third experiment the eggs were stored ( $0-246 \mathrm{~min})$ in $17 \% \mathrm{~S}$ sea water at $7{ }^{\circ} \mathrm{C}$ prior to their fertilization with the sperm dilution stored (26-267 min) at $4{ }^{\circ} \mathrm{C}$. The decision to store eggs in $17 \% \mathrm{~S}$ sea water was made on the basis of the results in the previous experiment. There, fertilization rates and percentage hatch of normal larvae were near-maximal for the $17 \%$ fertilization salinity (Fig. 2). Fertilization rates were 10-15\% higher during the first 2 hr of storage in $17 \% \mathrm{~S}$ sea water (Table 6), compared with the first experiment where the eggs were held for a comparable period (Table 2) in the humidity chamber. Control levels of fertilization or better also were extended from about $60 \mathrm{~min}$ for eggs stored in the humidity chamber to about $2 \mathrm{hr}$ for eggs stored in $17 \% 0 \mathrm{~S}$ sea water. In addition, the discoloration of the jelly coat of eggs stored "dry" (Expt. 1) was not seen among the eggs stored in $17 \% 0 \mathrm{~S}$ sea water. As noted in the first experiment (Fig. 1), there is again a suggestion that storage of milt (1:8 dilution with $17 \% 0 \mathrm{~S}$ sea water) for 1-2 hr (Table 6) may improve its fertilization potential slightly, over that provided by a freshly prepared dilution of milt. A final check of the fertilization potential of the milt dilution $7 \mathrm{hr}$ after its preparation yielded a fertilization rate of about $85 \%$. Hence the decline in fertilization rates in Table 6 may be attributed largely to a decline in fertilization potential of the eggs rather than the sperm. 
Table 7

Effect of the salinity of the storage medium on subsequent fertilization rates for Pacific herring eggs. Temperatures: milt dilution storage, $4^{\circ} \mathrm{C}$; egg storage and fertilization, $7{ }^{\circ} \mathrm{C}$

\begin{tabular}{|cccccc|}
\hline $\begin{array}{c}\text { Storage } \\
\text { salinity } \\
(\% 0)\end{array}$ & $\begin{array}{c}\text { Storage time } \\
\text { Eggs } \\
(\mathrm{min})\end{array}$ & $\begin{array}{c}\text { Milt } \\
(\mathrm{min})\end{array}$ & \multicolumn{2}{c}{$\begin{array}{c}\text { Eggs fertilized } \\
\text { Sample }\end{array}$} & $\begin{array}{c}\text { Fertilization } \\
\text { rate } \\
(\%)\end{array}$ \\
\hline 10 & 61 & 49 & $194 / 198$ & $182 / 197$ & 95.2 \\
12 & 62 & 50 & $257 / 258$ & $201 / 217$ & 96.4 \\
15 & 62 & 51 & $241 / 245$ & $151 / 160$ & 96.8 \\
17 & 61 & 50 & $108 / 122$ & $257 / 274$ & 92.2 \\
20 & 63 & 52 & $163 / 206$ & $185 / 210$ & 83.7 \\
22 & 63 & 52 & $119 / 149$ & $128 / 185$ & 74.0 \\
25 & 63 & 53 & $142 / 182$ & $121 / 150$ & 79.0 \\
27 & 63 & 53 & $110 / 177$ & $87 / 133$ & 63.6 \\
30 & 64 & 54 & $93 / 137$ & $84 / 138$ & 64.4 \\
\hline
\end{tabular}

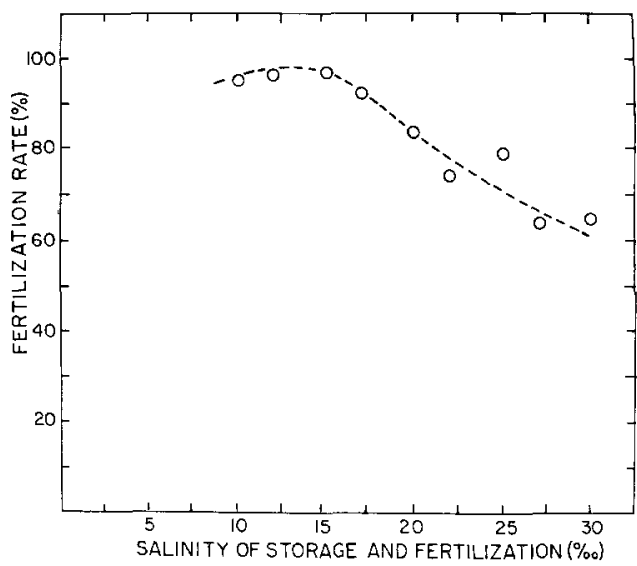

Fig. 4: Fertilization rates of eggs after $1 \mathrm{hr}$ of storage in salinities from 10 to $30 \% 0$ at $7^{\circ} \mathrm{C}$ using standard milt dilution $\left(1: 8\right.$ with $17 \%$ S sea water) stored at $7^{\circ} \mathrm{C}$

In summary, eggs stored in $17 \% \mathrm{~S}$ sea water at $7{ }^{\circ} \mathrm{C}$ provided control levels of fertilization or better $(90-96 \%)$ for a period of about $2 \mathrm{hr}$. Maximum fertilization rates were about $10-15 \%$ greater, and lasted about $1 \mathrm{hr}$ longer, than those obtained from eggs stored in the humidity chamber. Fertilization potential of the eggs declined more rapidly than the milt, and storage of the milt dilution at $4{ }^{\circ} \mathrm{C}$ for 1-2 hr appears to increase its fertilization potential by about $5 \%$ over control levels.

In the fourth experiment, the "wet" method of storing herring eggs prior to fertilization (Expt. 3) was extended to examine the influence of the salinity of the storage medium on subsequent fertilization success (Table 7). Storage times, about $1 \mathrm{hr}$ for both the eggs and the milt dilution, were fixed to check and maximize the result anticipated on he basis of the previous experiments. High rates of fertilization were obtained for eggs stored in salinities of 10-17\% \% highest rates occurred in 
fertilization salinities of $12-15 \%$ (Fig. 4). Fertilization rates for eggs stored in salinities higher than $17 \%$ showed a marked decline. Therefore the fertilization potential of eggs stored for $1 \mathrm{hr}$ at $7{ }^{\circ} \mathrm{C}$ prior to fertilization appears to be maximized at storage salinities of $12-15 \%$.

\section{DISCUSSION}

Live teleost gametes are not always at the investigator's immediate disposal, and often it is impractical to transport the ripe adults from the point of capture to the place of use. For these reasons, short-term storage techniques have been evolved for successful transportation of the gametes (Blaxter \& Holliday, 1963). Teleost eggs retain their fertilization potential longest when stored in cavity fluid or ovarian fluid (Ginzburg, 1972); it is presumed that the success of the technique developed for dry storage of Atlantic herring eggs (Blaxter, 1955) results from the fact that eggs stored in intact gonadal segments would remain largely in contact with ovarian fluid. In the dry storage technique employed here, the eggs in the prepared samples were in minimal contact with ovarian fluid and the major problem appeared to be the prevention of desiccation of the eggs during storage.

The objective of the current enquiry, however, was to define a technique allowing the preparation of egg samples over a period of time and in such a manner that all samples would retain a high fertilization potential prior to later synchronous fertilization. Results of the several experiments conducted to examine this strategy are summarized in Table 8.

High rates of egg fertilization occurred in salinities of 10 to $30 \%$, and highest rates were associated with salinities of 10 to $20 \%$ (Fig. 1). Closer examination of the later range (Fig. 4) shows fertilization rates were maximized at salinities between 12 and $15 \%$. Salinities associated with fertilization rates of $50 \%$ or greater range from 4.5 to $42 \%$, substantiated by the hatches obtained for groups of eggs fertilized in the various salinities $\left(0-45 \%\right.$ ) and incubated in $17 \% \mathrm{~S}$ sea water at $7{ }^{\circ} \mathrm{C}$ (Table 8). The latter salinity-temperature combination would be near-optimal for egg development, once fertilization has occurred (Alderdice \& Velsen, 1971). Galkina (1957) also noted that percentage fertilization of Pacific (Okhotsk) herring eggs was reduced at salinities below $5 \%$. In comparison, Holliday \& Blaxter (1960) found that maximum fertilization rates were obtained for Atlantic herring eggs fertilized in salinities of $22.7-52.5 \%$; $70 \%$ fertilization was obtained in $5.9 \%$, the lowest salinity examined.

The remaining results for the second experiment (Table 8) are of interest in the fact that exposure to various salinities, at fertilization and for a $2^{1 / 2}-\mathrm{hr}$ period thereafter, had a continuing influence on egg development, even though the eggs were subject to identical conditions $\left(17 \% \mathrm{~S}, 7^{\circ} \mathrm{C}\right)$ for the balance of the incubation period. That is, the incubation periods for eggs fertilized in low salinities $(2.5,5 \%)$ were shorter, the eggs were slightly larger in diameter, and the larvae ultimately produced were larger in comparison with the results obtained for eggs fertilized in 
Short-term storage of gametes

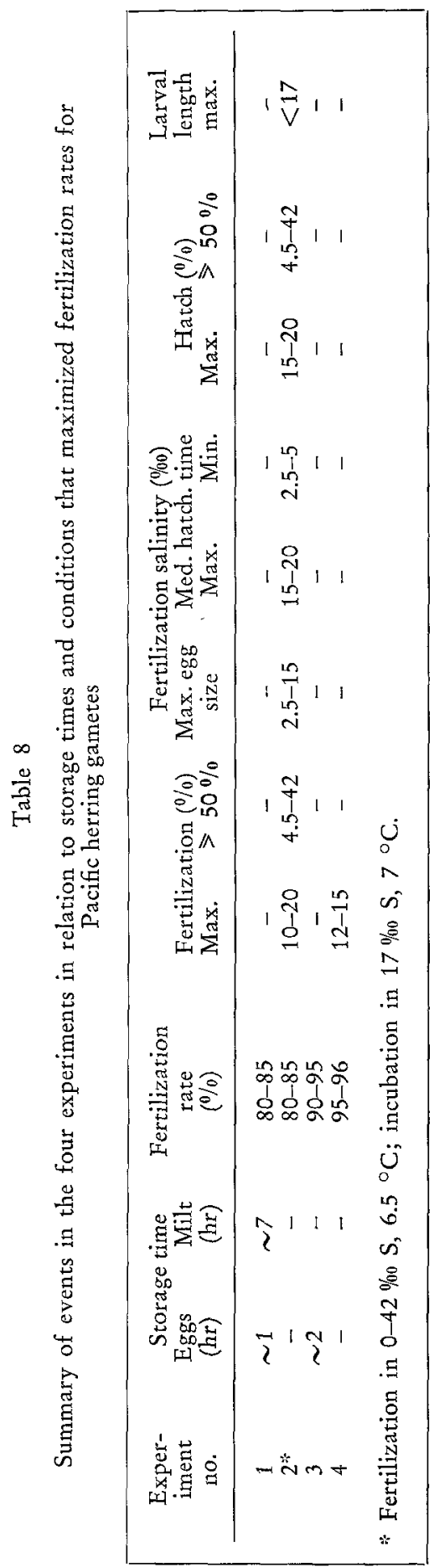


$15-20 \% \mathrm{~S}$. The observations resemble those associated with irreversible nongenetic adaptation (Kinne, 1962), whereby induced adjustments may occur in the organism as a result of differences in early life history - adjustments of a nongenetic nature that may modify the individual during its life span. We suspect that the differences in egg diameter noted are the result of irreversible changes occurring in the egg capsule during water hardening, which we presume would have begun within the $2^{1 / 2-h r}$ period of exposure to the fertilization salinity. Other evidence suggests that changes in osmoconcentration of the yolk of unfertilized eggs may occur during storage (Holliday \& Jones, 1965), during fertilization, and during imbibition when the forming perivitelline fluid surrounding the yolk would be influenced by the imbibed fertilization medium. In all of these stages the exchange coefficient of the vitelline membrane would be relatively high (Loeffler, 1971), although it begins to decrease after fertilization. In addition, volume changes associated with imbibition are $50 \%$ complete in 1 to $1 \frac{1}{2} \mathrm{hr}$ in Pacific herring eggs in salinities of 5 to 35 (Alderdice et al., 1979). 'These relations suggest that ionic and osmotic properties of the yolk may have become "fixed" during the $21 / 2$-hr period of exposure to the fertilization salinity to an extent sufficient to modify some aspects of subsequent development. In any event, the point to be made is the fact that the salinity to which the egg is exposed during storage and fertilization can have a measurable effect on subsequent events during embryonic development.

In two instances where the milt dilution was stored and its fertilizing capacity was tested periodically, there was an apparent increase in its fertilization potential to a level greater than that obtained initially. When the stored milt dilution was used to fertilize freshly stripped eggs (Table 2, Fig. 1), fertilization potential was lower in the first $100 \mathrm{~min}$ than in the following $300 \mathrm{~min}$ or more. A similar trend is noted in the third experiment (Table 6); there fertilization rates were higher, for milt stored 57 to $147 \mathrm{~min}$, than in the initial trials. The results in the third experiment presumably are confounded by declining fertilization potential of the eggs, concurrently stored, which would mask any continuing high fertilization capacity of the stored sperm. The reasons for these delayed increases in fertilization potential are not known, although they tend to resemble observations of sperm reactivation discussed by Ginzburg (1972). In such instances, dilutions of sperm may lose fertilizing capacity during storage. After a period of quiescence, fertilization potential may be partly restored by the addition of water to the sperm. Reactivation appears to be associated with renewal of energy reserves during sperm quiescence.

In general, storage of Pacific herring egg samples at $4^{\circ} \mathrm{C}$ by the dry method employed would be satisfactory for egg storage not exceeding $1 \mathrm{hr}$. On the other hand, wet storage $\left(7^{\circ} \mathrm{C}\right)$ extended the acceptable storage time to $2 \mathrm{hr}$, increased the fertilization rate by about $10 \%$, and prevented patchy discoloration of the jelly coat. The latter bore no apparent relation to fertilization success, but it would render subsequent observation of developmental events more difficult. Ultimate maximum fertilization rates were obtained for eggs stored and fertilized in salinitiss of 12-15\%. Based on the results, a storage temperature of $4{ }^{\circ} \mathrm{C}$ has been used in subsequent investigations, recognizing that storage of both gametes may be extended successfully at lower temperatures (Ginzburg, 1972; Withler \& Morley, 1968). The 
technique therefore provides for short-term storage of eggs, prior to fertilization, for a maximum period of $2 \mathrm{hr}$ in $12-15 \%$ sea water at $4{ }^{\circ} \mathrm{C}$.

Under experimental conditions when maximum rates of fertilization are desired, the eggs may be fertilized in 12-15\% S followed by their transfer to other salinities. In practice, we have limited fertilization salinities to a maximum of $20 \% 0$ view of the lower fertilization rates and hatching success to be expected at higher fertilization salinities. It should be remembered that the exchange coefficient of the perivitelline membrane is high prior to fertilization (Loeffler, 1971), and that storage of eggs in a given salinity will modify osmotic properties of the unfertilized egg (Holliday \& Jones, 1965). Therefore yolk osmoconcentration and egg volume may be influenced by the previous salinity experience, if stored eggs are to be transferred to other salinities following fertilization. We assume this is the primary cause of the variations in length of the incubation period, and larval size at hatching, noted in this study (Expt 2). It appears that such effects may be magnified if transfer of eggs after fertilization does not occur prior to the period beginning with imbibition and ending with the completion of water hardening (Alderdice et al., 1979).

\section{ZUSAMMENFASSUNG}

Für zahlreiche Untersuchungen über den Einfluß von Umweltfaktoren auf die Ontogenese von Fischen besteht die Notwendigkeit, große Versuchsserien mit hohen Eizahlen zeitlich anzusetzen (z. B. je 400 Eier in je 15 Versuchskombinationen mit jeweils 4 Replikaten). Werden Heringseier für jede Versuchsreihe dem Muttertier nacheinander entnommen und für die Befruchtung vorbereitet, so kann zwischen der ersten und letzten Probe ein erheblicher Zeitunterschied bezogen auf den Befruchtungszeitpunkt entstehen. Die Eier werden in der Regel also unterschiedlich lange vor der Befruchtung zwischengehältert. Dies kann ihre Befruchtungsfähigkeit und auch die Sterblichkeit während der Ontogenese beeinflussen und auf diese Weise die Versuchsergebnisse von Kontaminationsexperimenten erheblich verfälschen. Es ist bekannt, daß Teleosteer-Eier unterschiedlich lange ihre Befruchtungsfähigkeit behalten (1 min bis mehrere Std.). In der vorliegenden Arbeit wurde die Befruchtungsfähigkeit der Eier des pazifischen Herings geprüf, nachdem diese unterschiedlich lange aufbewahrt worden waren. Zwei Methoden wurden dabei angewendet: (1) die sogenannte "nasse" Methode, bei der die auf Nylongaze selbsthaftenden Eier unter Wasser verschieden lange aufbewahrt wurden. Die Versuche wurden in 9 Salzgehaltsstufen zwischen 10 und $30 \% \mathrm{~S}$ und bei zwei Temperaturen $\left(4^{\circ} \mathrm{C}\right.$ und $\left.7{ }^{\circ} \mathrm{C}\right)$ durchgeführt. (2) Die sogenannte "trockene" Methode, bei der die Eier in einer feuchtigkeitsgesättigten Kammer bei $4{ }^{\circ} \mathrm{C}$ gehältert wurden. Die Versuche wurden in 12 Salzgehaltsstufen zwischen $\mathrm{O}$ und $45 \% \mathrm{~S}$ durchgeführt. Ausgezeichnete Ergebnisse wurden mit der nassen Methode erzielt. Die höchsten Befruchtungsraten wurden in Salzgehalten $z$ wischen 12 und 15\% $S$ beobachtet (90-96\%). Befruchtungsraten um und übes $50 \%$ wurden bei unterschiedlich langer Aufbewahrungszeit der Eier vor der Befruchtung in Salzgehalten zwischen 4,5 und $42 \% 0 \mathrm{~S}$ erreicht. Die Eier behielten eine hohe Befruchtungsfähigkeit bei Aufbewahrungszeiten bis zu zwei Stunden. Auf 
Grund der vorliegenden Versuchsergebnisse wird empfohlen, die Eier des pazifischen Herings vor der Befruchtung bei $12-15 \% \mathrm{~S}$ und $4{ }^{\circ} \mathrm{C}$ nicht länger als zwei Stunden aufzubewahren. Die "trockene" Aufbewahrungsmethode hat sich nicht bewährt. Wurde Heringsmilch im Verhältnis 1:8 mit Seewasser (17\% S) verdünnt und bei $4^{\circ} \mathrm{C}$ aufbewahrt, so verbesserte sich die Befruchtungsfähigkeit leicht nach etwa zwei Stunden und blieb bis zu 7 Std. erhalten. Der Salzgehalt des Seewassers zum Befruchtungszeitpunkt bestimmt die Eigröße, Inkubationszeit und Larvengrößen zum Schlupfzeitpunkt auch dann, wenn die Eier $2^{1 / 2}$ Std. nach der Befruchtung in $17 \% 0 \mathrm{~S}$ und $7^{\circ} \mathrm{C}$ überführt und bis zum Schlupf inkubiert wurden.

\section{LITERATURE CITED}

Alderdice, D. F. \& Velsen, F. P. J., 1971. Some effects of salinity and temperature on early development of Pacific herring (Clupea pallasi). J. Fish. Res. Bd Can. 28, 1545-1562.

- Rao, T. R. \& Rosenthal, H., 1979. Osmotic responses of eggs and larvae of the Pacific herring to salinity and cadmium. Helgoländer wiss. Meeresunters. 32 (In press).

- Rosenthal, H. \& Velsen, F. P. J., 1979. Influence of salinity and cadmium on the volume of Pacific herring eggs. Helgoländer wiss. Meeresunters. 32 (In press).

Blaxter, J. H. S., 1955. Herring rearing - I. The storage of herring gametes. Mar. Res. 3, 1-12.

- \& Holliday, F. G. T., 1963. The behaviour and physiology of herring and other clupeids. Adv. mar. Biol. 1, 261-393.

Galkina, L. A., 1957. Effect of salinity on the sperm, eggs and larvae of the Okhotsk herring. Izv. tikhookean. nauchno-issled. Inst. ryb. Khoz. Okeanogr. 45, 35-70.

Ginzburg, A. S., 1972. Fertilization in fishes and the problem of polyspermy. Israel Program for Scientific Translation, Jerusalem, $366 \mathrm{pp}$.

Holliday, F. G. T., \& Blaxter, J. H. S., 1960. The effects of salinity on the developing eggs and larvae of the herring. J. mar. biol. Ass. U.K. 39, 521-603.

- \& Jones, M. P., 1965. Osmotic regulation in the embryo of the herring (Clupea barengus). J. mar. biol. Ass. U.K. 45, 305-311.

Kinne, O., 1962. Irreversible nongenetic adaptation. Comp. Biochem. Physiol. 5, 265-282.

Loeffler, C. A., 1971. Water exchange in the pike egg. J. exp. Biol. 55, 797-811.

Withler, F. C., \& Morley, R. B., 1968. Effects of chilled storage on viability of stored ova and sperm of sockeye and pink salmon. J. Fish. Res. Bd Can. 25, 2695-2699.

Yanagimachi, R., 1953. Effect of environmental salt concentration on fertilizability of herring gametes. J. Fac. Sci. Hokkaido Univ. (Ser. 6) 11, 481-486. 